\title{
PHYTONCIDE ACTIVITY OF WOODY PLANTS UNDER THE CONDITIONS OF STEPPE ZONE
}

\author{
SVETLANA VOLODARETS ${ }^{1}$, ALEKSANDR GLUKHOV², IRINA ZAITSEVA ${ }^{3}$ \\ ${ }^{1}$ Dnipropetrovsk State Agrarian and Economic University, Department of Landscape and Economy, Dnipro, \\ Ukraine; e-mail: svetlana_volodarez@i.ua \\ ${ }^{2}$ Donetsk Botanical Garden, Department of Dendrology and Natural Flora, Donetsk, Ukraine \\ ${ }^{3}$ Oles Honchar Dnipro National University, Department of Plants Physiology and Introduction, Ukraine
}

\begin{abstract}
Volodarets S., Glukhov A., Zaitseva I.: Phytoncide activity of woody plants under the conditions of steppe zone. Ekológia (Bratislava), Vol. 37, No. 3, p. 219-229, 2018.

The study of phytoncide activity of biogenic volatile organic compounds of woody plants is one of the most important areas of research in plant ecology in urban lands. The aim of this work is to investigate the dependence of the phytoncide activity of some woody plant species from meteorological factors in the urban environment in the steppe zone of Ukraine. The objectives of the investigation were 28 species of trees and shrubs. The air temperature is indicated to be a major factor for drought-resistant and some medium drought-resistant species (Populus simonii Carrière, Armeniaca vulgaris L., Robinia pseudoacacia L., Acer pseudoplatanus L., Malus niedzwetzkyana Dieck). The phytoncide activity of low and medium drought-resistant species (Viburnum opulus L., Acer sacharinnum L.) depends on air humidity and total monthly precipitation. The obtained results make it possible to predict changes in the phytoncide activity of woody plants, when selecting the assortment of species for phyto-optimization of technogenic environment.
\end{abstract}

Key words: woody species, antiprotozoal activity, temperature, humidity, precipitation, arid zone.

\section{Introduction}

During their vital activity, woody plants release biogenic volatile organic compounds (BVOC) into the air, which are a volatile form of phytoncides. Phytoncides are one of the many factors, influencing the air microflora composition under the conditions of different plant associations, and regulate the composition of living organisms in biogeocenosis. These compounds regulate the interaction of organisms in the urban environment and maintain the balance of pathogenic microflora in the air of the city. They also limit the rising of pathogenic microflora for human.

Ability of BVOC to suppress the growth and development of bacteria and protozoa phytoncide activity (PA), depends on meteorological factors, phenological phase and vital condition of a plant. The ability to produce phytoncides is closely related to the age of plants, their development in ontogenesis, and has seasonal nature, that is, in different seasons and vegetative phases, different organs of the same plant have different activities (Fuentes et al., 2000; Duhl et al., 2008; Dewulf et al., 2012). 
The largest amount of volatile compounds with high phytoncide activity is secreted by the young organs of plants. As their age increases, this activity decreases (Pennuelas, Llusia, 2001). A more complex dependence is observed depending on the age and the vegetative phase of plants. Along with photosynthetic activity and growth processes, an important role is played by an increase in the mass of the assimilation apparatus of plants (Kesselmeier, Staudt, 1999).

Volatile organic compounds are synthesized as secondary metabolites in the cytoplasm and cell organelles of plants. Biogenetic precursors of these compounds are: mevalonate, acetyl-coa, cinnamic acid and amino acids. Water-soluble compounds accumulate in vacuoles, whereas gaseous and lipophilic substances are emitted into the free space of a cell, from where they are extracted out of the plant organism (Roschina V.V., Roshchina V.D., 2012; Harley, 2013; Harley et al., 2014).

The research area is located in the southeast of Ukraine with complex forest vegetation and technogenic conditions (State of the Natural Environment, 2010). High temperatures and insufficient precipitation have weakened woody plants; therefore, forest communities do not treat a zonal type of vegetation of a steppe zone. In such conditions, the problem of influence of abiotic factors (temperature, humidity and precipitation) on the emission of secondary metabolites, particularly phytoncides, as one of the expressions of vital activity of the plant organism, is important and promising. This question is especially relevant for the urbanized (industrial) territories, as it has been established through previous researches that in the conditions of aerogenic contamination, drought-resistant species find out greater firmness exactly at which the mechanisms of adaptation to the drought operate in the conditions of industrial pollution, as preadaptations to aerotoxicants (Fowler, 2002; Hopke, 2009; Korshikov, 2004; Kulagin, 1985).

The BVOC emission, particularly isoprenes and monoterpenes, depends on the light intensity and air temperature (Davison et al., 2009). Mathematical models were developed to calculate the amount of isoprenes, emitted by trees, for example, MEGAN (Guenther et al., 2006; 2012).

In the CIS countries, the models for influence of abiotic factors (light, temperature and humidity) on phytoncide activity were developed only for Quercus rubra L. and Pinus kochiana Klotzsch ex K. Koch (P. hamata [Steven] Sosn.) (Slepyih, 2004). Since the phytoncide activity depends on the microclimatic conditions of woody plant growth, it is essential to take into account the influence of meteorological factors during the investigation of BVOC at the regional level to determine the influence of temperature and humidity on the phytoncide activity of woody plants and to build a statistical model for species with the highest phytoncide activity. The purpose of this paper was to find out the dependence of phytoncide activity of woody plants on weather conditions in the region of a steppe zone, to carry out its quantitative assessment and to construct the prognostic statistical model of a temperature effect, air humidity and an amount of precipitation on the phytoncide activity for some species.

\section{Material and methods}

The objects of research were 28 species of deciduous plants. They grow on sites of the Donetsk Botanical Garden of the NAS of Ukraine, which is located beyond the main sources of pollution.

According to the physical and geographical regionalization, the research area belongs to the north-steppe subzone of the steppe zone (Lipinskogo et al., 2003). The climate of the research area is moderately continental of the mid-latitude steppe, characterized by aridity during the summer. The humidity coefficient is about 0.8 , the annual precipitation is from 440 to $460 \mathrm{~mm}$, including that of the warm season from 216 to $290 \mathrm{~mm}$. 
As shown in Figure 1, the investigation was conducted during two vegetative periods that contrasted on precipitation and temperature - in the condition of a long dry period and in the related normal conditions for the investigated region for hydrothermal regime, in the example of years 2010 and 2011.

The plant material was collected monthly at solar windless weather from May to September. For the study, we took healthy, undamaged leaves, without signs of chlorosis, around the perimeter of the crown (from the southern, northern, eastern and western parts), from the lower layer. The leaves were collected from 7-8 trees to obtain the average sample.

The monthly temperature, humidity and the sum precipitations for Donetsk were used during the investigation from Ukraine National Hydro Meteorological Center (Ukrayinskii hidrometeorolohichnyi tsentr).

When determining the growth stages of deciduous plants, we used the method of visual observation (Zaitseva, 2003; Methodology of phenological observation, 1979). We distinguished the following development phases of the

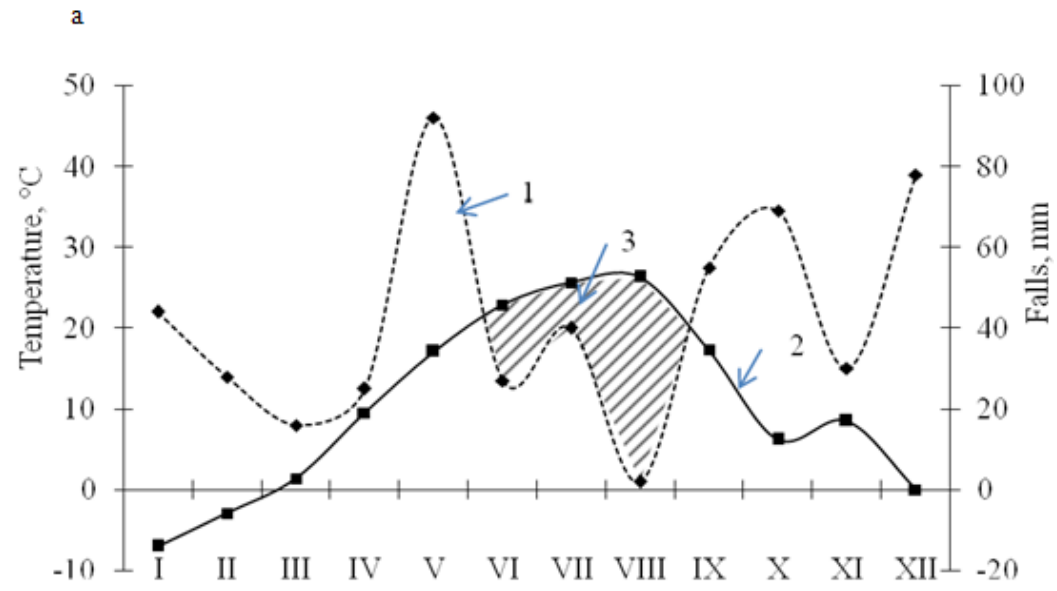

b

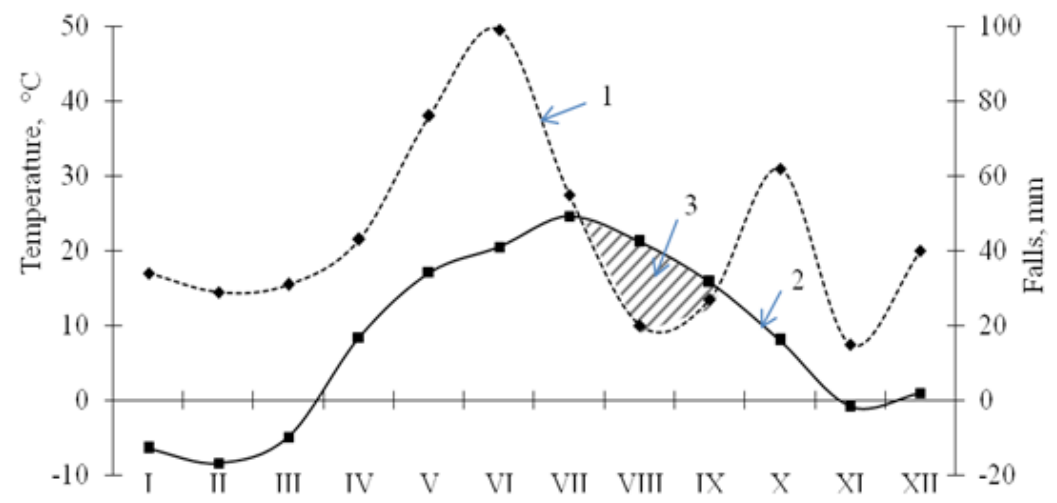

Fig. 1. Walter-Lieth climate diagram in Donetsk in the years of research: a - 2010, b- 2011.

Notes: 1 - the value of the amount of precipitation for month, $\mathrm{mm}, 2$ - the value of monthly average temperature, ${ }^{\circ} \mathrm{C}, 3$ - drought period. 
woody plant shoots: the phase of active growth (from the leaf-out, beginning of shoot growth), the phase of secondary growth (end of shoot elongation, formation of the apical bud, summer vegetation), the phase of deep (physiological) rest - suspension of all growth processes in the late summer and early autumn. The terms of phenological changes were recorded in days after the first of March from starting the positive temperatures (Zaitseva, 2003). The investigated species have changed the term of growth period from 129 to 222 days.

The antiprotozoal activity of leaves was determined according to the 'hanging drop' technique (Tokin, 1980), in 5 times. We used the culture Paramecium caudatum Ehr. as a test object. With a total arrest of motion, we stated the death of $P$. caudatum, followed by the granular decay of its body.

Phytoncide activity was calculated from the formula:

$$
\mathrm{A}=100 / \mathrm{T}\left(\mathrm{min}^{-1}\right)
$$

where A is phytoncide activity in terms of phytoncide ability - $\min ^{-1}, \mathrm{~T}$ is time of death of $50 \%$ P. caudatum (Grodzinskiy, 1973).

Mathematical treatment of the data was conducted by the single-factor analysis of variance (ANOVA), using the Tukey's test and Levene's test. Next, we determined the relationship between the average monthly indicators of meteorological factors (temperature, humidity and precipitation) and the average monthly phytoncide activity with the use of stepwise regression analysis. Then, we defined the Durbin-Watson statistic and a serial correlation in Statistica 10.0.

\section{Results and discussion}

As a result of the ANOVA analysis, it was stated that the character of phytoncide activity varies during the vegetative season and is species-specific as shown in Table 1 and Table 2. Based on the Tukey's posteriori analysis, we distinguished a group of woody plants having the maximum PA in a certain vegetative phase: in the phase of active shoot growth (Padus avium Mill.), in the phase of secondary shoot growth (27 species) with the maximum in June - Populus $\times$ canadensis Moench and Malus niedzwetzkyana Dieck, in July - 10 species and 13 species in August. Ulmus laevis Pallas. don't have a maximum, and Sorbus intermedia (Ehrh.) Pers have the maximum PA in July and August.

As shown in Table 3, the factors influencing PA are heterogeneous according to the results of stepwise regression analysis for the first group.

For Padus avium, which is an exception to the general pattern, the major factor is precipitation (B $>1$ ), as this species likes moisture conditions. According to the ecomorphological relation to the moisture, P. avium is mesophyte. 146\% of normal precipitation fell in May 2011.

$P$. avium sensitively reacts to the favourable conditions of humidifying by an increase of the level of the vital activity. This possibility is reflected at an increase of its phytoncide activity. Moreover, the major factor is a vegetative phase. This dependence is shown by the means of two equations of regression with two variables: phenophase and air temperature; phenophase and amount of precipitation as imaged in Figure $2 \mathrm{a}, \mathrm{b}$, with $\mathrm{R}^{2}=0.91$ and $\mathrm{R}^{2}=0.83$. For other species, we constructed laniary dependence between temperature and humidity or precipitation, or influence only of temperature is established. For P. avium, the impact of phenophase is exactly determined, as for mesophilous species according to the moisture.

The antiprotozoal activity of this species positively correlates with the rising of the temperature in the period of active growth of vegetative organs - the shoots and leaves. In the phase of secondary shoot growth (July, 146 days), PA decreases, because initial substances forming BVOC are used during the fruiting period of $P$. avium. This tendency can be explained by the chemical 
T a b l e 1. Antiprotozoal activity $\left(\mathrm{min}^{-1}\right)$ of deciduous woody plants in hydrothermal conditions, typical for the area of researches, $\mathrm{M} \pm \mathrm{m}, \mathrm{n}=5$, all the data is significant at $\mathrm{p} \leq 0.05$, bold type - antiprotozoal activity peak.

\begin{tabular}{|c|c|c|c|c|c|c|}
\hline \multirow{2}{*}{ № } & \multirow{2}{*}{ Species } & \multicolumn{5}{|c|}{ Months } \\
\hline & & May & June & July & August & September \\
\hline 1. & Betula pendula Roth & $5.4 \pm 0.20$ & $6.2 \pm 0.48$ & $6.4 \pm 0.20$ & $5.9 \pm 0.12$ & $3.8 \pm 0.07$ \\
\hline 2. & Junglans regia $\mathrm{L}$. & $8.2 \pm 0.47$ & $10.8 \pm 0.49$ & $13.2 \pm 0.54$ & $13.6 \pm 0.93$ & $12.1 \pm 1.10$ \\
\hline 3. & Populus bolleana Lauche & $5.5 \pm 0.14$ & $6.0 \pm 0.18$ & $6.3 \pm 0.19$ & $5.2 \pm 0.10$ & $4.9 \pm 0.11$ \\
\hline 4. & P. $\times$ canadensis Moench & $5.7 \pm 0.21$ & $7.5 \pm 0.17$ & $6.8 \pm 0.27$ & $6.0 \pm 0.19$ & $5.5 \pm 0.64$ \\
\hline 5. & P. simonii Carrière & $6.5 \pm 0.22$ & $8.4 \pm 0.34$ & $14.4 \pm 0.67$ & $7.8 \pm 0.31$ & $5.7 \pm 0.22$ \\
\hline 6. & Salix alba L. & $4.3 \pm 0.12$ & $5.3 \pm 0.15$ & $7.0 \pm 0.13$ & $4.5 \pm 0.14$ & $3.2 \pm 0.07$ \\
\hline 7. & Tilia cordata Mill. & $7.4 \pm 0.23$ & $6.2 \pm 0.13$ & $13.8 \pm 0.44$ & $12.1 \pm 0.46$ & $6.5 \pm 0.18$ \\
\hline 8. & Ulmus pumila L. & $3.5 \pm 0.08$ & $4.7 \pm 0.11$ & $5.4 \pm 0.15$ & $6.5 \pm 0.19$ & $3.8 \pm 0.10$ \\
\hline 9. & U. laevis Pallas & $1.4 \pm 0.02$ & $1.6 \pm 0.02$ & $1.5 \pm 0.03$ & $1.4 \pm 0.02$ & $1.3 \pm 0.02$ \\
\hline 10. & Morus alba $\mathrm{L}$. & $1.7 \pm 0.02$ & $2.4 \pm 0.03$ & $3.2 \pm 0.07$ & $1.8 \pm 0.02$ & $1.7 \pm 0.03$ \\
\hline 11. & Armeniaca vulgaris $\mathrm{L}$. & $8.0 \pm 0.36$ & $9.0 \pm 0.35$ & $8.4 \pm 0.27$ & $11.9 \pm 0.39$ & $6.7 \pm 0.41$ \\
\hline 12. & Malus niedzwetzkyana Dieck & $4.7 \pm 0.09$ & $6.2 \pm 0.11$ & $5.6 \pm 0.22$ & $5.2 \pm 0.17$ & $4.3 \pm 0.13$ \\
\hline 13. & Padus avium Mill. & $12.4 \pm 0.51$ & $8.5 \pm 0.37$ & $6.3 \pm 0.19$ & $6.6 \pm 0.29$ & $5.1 \pm 0.09$ \\
\hline 14. & Pyrus communis L. & $6.6 \pm 0.24$ & $7.7 \pm 0.19$ & $9.0 \pm 0.41$ & $14.6 \pm 0.83$ & $8.2 \pm 0.35$ \\
\hline 15. & Sorbus aucuparia L. & $5.2 \pm 0.23$ & $6.1 \pm 0.21$ & $6.8 \pm 0.42$ & $8.3 \pm 0.45$ & $4.7 \pm 0.15$ \\
\hline 16. & S. intermedia (Ehrh.) Pers & $4.6 \pm 0.10$ & $5.0 \pm 0.23$ & $5.6 \pm 0.22$ & $5.6 \pm 0.15$ & $4.3 \pm 0.15$ \\
\hline 17. & Robinia pseudoacacia L. & $5.7 \pm 0.13$ & $8.8 \pm 0.27$ & $7.3 \pm 0.26$ & $10.4 \pm 0.53$ & $4.9 \pm 0.18$ \\
\hline 18. & Aesculus hippocastanum L. & $4.2 \pm 0.09$ & $5.8 \pm 0.21$ & $8.6 \pm 0.18$ & $4.8 \pm 0.10$ & - \\
\hline 19. & Acer negundo L. & $7.8 \pm 0.32$ & $8.9 \pm 0.27$ & $10.7 \pm 0.33$ & $14.1 \pm 0.57$ & $7.4 \pm 0.29$ \\
\hline 20. & A. platanoides L. & $6.3 \pm 0.16$ & $8.5 \pm 0.36$ & $9.6 \pm 0.61$ & $7.1 \pm 0.31$ & $6.2 \pm 0.26$ \\
\hline 21. & A. pseudoplatanus L. & $5.5 \pm 0.13$ & $6.2 \pm 0.14$ & $8.6 \pm 0.26$ & $7.6 \pm 0.15$ & $5.2 \pm 0.12$ \\
\hline 22. & A. saccharinum $\mathrm{L}$. & $2.6 \pm 0.04$ & $2.7 \pm 0.05$ & $3.0 \pm 0.08$ & $7.7 \pm 0.21$ & $5.1 \pm 0.14$ \\
\hline 23. & $\begin{array}{l}\text { Ailanthus } \\
\text { altissima (Mill.) Swingle }\end{array}$ & $4.3 \pm 0.13$ & $5.0 \pm 0.16$ & $5.7 \pm 0.27$ & $6.8 \pm 0.29$ & $3.9 \pm 0.08$ \\
\hline 24. & Viburnum opulus L. & $5.9 \pm 0.21$ & $6.6 \pm 0.34$ & $8.4 \pm 0.42$ & $10.7 \pm 0.76$ & $5.5 \pm 0.21$ \\
\hline 25. & $\begin{array}{l}\text { Symphoricarpos } \\
\text { albus (L.) S. F. Blake }\end{array}$ & $5.8 \pm 0.21$ & $6.5 \pm 0.27$ & $7.3 \pm 0.27$ & $7.9 \pm 0.10$ & $6.5 \pm 0.18$ \\
\hline 26. & Forsythia ovata Nakai & $8.0 \pm 0.24$ & $7.9 \pm 0.31$ & $9.1 \pm 0.31$ & $11.7 \pm 0.64$ & $9.9 \pm 0.60$ \\
\hline 27. & Ligustrum vulgare L. & $3.3 \pm 0.05$ & $3.9 \pm 0.09$ & $4.4 \pm 0.09$ & $5.1 \pm 0.14$ & $4.3 \pm 0.12$ \\
\hline 28. & Syringa vulgaris L. & $6.4 \pm 0.20$ & $7.4 \pm 0.22$ & $7.5 \pm 0.16$ & $7.8 \pm 0.31$ & $6.3 \pm 0.18$ \\
\hline
\end{tabular}

T a b le 2. Multivariate test of significance sigma-restricted parameterization effective hypothesis decomposition.

\begin{tabular}{|c|c|c|c|c|c|c|}
\hline & Test & Value & F & Effect - df & Error - df & P \\
\hline Intercept & Wilks & 0.001473 & 2881,227 & 4 & 17.00000 & 0.000000 \\
\hline Season & Wilks & 0.013973 & 10,011 & 16 & 52.57348 & 0.000000 \\
\hline
\end{tabular}

composition of leaves of this species; the amygdalin can be synthesized and emitted outside during the flowering and the fruit ripening period. The hydrocyanic acid cannot be formed in intact 
T a b l e 3. Stepwise regression analysis for phytoncide activity of woody plants in the vegetative period of 2011 . Negatively correlated variables are made in bold. Statistical significance, $\mathrm{p}$-value: $<0.05={ }^{*} ;<0.001={ }^{* *} ;<0.0001^{\star * *}$.

\begin{tabular}{|c|c|c|c|}
\hline Species & Step 1 & Step 2 & Step 3 \\
\hline Betula pendula & Temp $0.69^{\star * *}$ & Temp Hum $0.41^{\star}$ & Temp Hum Falls $0.61^{* * *}$ \\
\hline Junglans regia & Falls $0.76^{\star *}$ & Falls Temp $0.50^{*}$ & Hum - \\
\hline Populus bolleana & Temp $0.63^{* * *}$ & Temp Falls $0.34^{\star}$ & - \\
\hline P. $\times$ canadensis & Falls $0.39^{*}$ & Falls Temp $0.54^{\star *}$ & - \\
\hline P. simonii & Temp $0.90^{* * *}$ & Temp Hum $0.33^{*}$ & - \\
\hline Salix alba & Temp $0.89^{* * *}$ & Temp Hum $0.17^{\star}$ & - \\
\hline Tilia cordata & Temp $0.82^{* * *}$ & Temp Hum & Temp Falls $-0.36^{*}$ \\
\hline Ulmus pumila & Temp $0.74^{* * *}$ & Temp Hum 0.41* & - \\
\hline U. laevis & Temp $0.61^{* * *}$ & Temp Falls $0.39^{\star}$ & - \\
\hline Morus alba & Temp $0.85^{\star * *}$ & Temp Hum $0.56^{* * *}$ & \\
\hline Armeniaca vulgaris & Temp $0.91^{\star * *}$ & - & - \\
\hline Malus niedzwetzkyana & Temp $0.64^{* * *}$ & Temp Falls $0.50^{\star *}$ & - \\
\hline Padus avium & Falls $1.15^{\star * *}$ & Falls Hum 0.76 ${ }^{* * *}$ & Falls Hum Temp 0.34 ${ }^{\star *}$ \\
\hline Pyrus communis & Hum 0.51 & Hum Temp $0.41^{\star *}$ & Hum Temp Falls 0.39 \\
\hline Sorbus aucuparia & Temp $0.64^{* * *}$ & Hum $0.55^{\star * *}$ & - \\
\hline S. intermedia & Temp $0.75^{\star *}$ & Hum 0.30* & - \\
\hline Robinia pseudoacacia & Temp $0.90^{* * *}$ & Hum $0.19^{*}$ & - \\
\hline Aesculus hippocastanum & Temp $0.87^{\star * *}$ & Falls $0.46^{\star * *}$ & Hum 0.21* \\
\hline Acer negundo & Hum 0.67 & Temp $0.61^{\star \star \star}$ & - \\
\hline A. platanoides & Temp $0.79^{* * *}$ & Hum $0.36^{*}$ & - \\
\hline A. pseudoplatanus & Temp $0.95^{* * *}$ & Falls $0.24^{* *}$ & - \\
\hline A. saccharinum & Falls 0.59*** & Hum 0.39* & - \\
\hline Ailanthus altissima & Temp $0.70^{* * *}$ & Hum $0.55^{\star \star}$ & \\
\hline Viburnum opulus & Hum 0.63 & Temp 0.62 & - \\
\hline Symphoricarpos albus & Temp $0.61^{\star * *}$ & Falls 0.55 $5^{\star \star}$ & - \\
\hline Forsythia ovata & Falls 0.77 & - & - \\
\hline Ligustrum vulgare & Falls 0.57** & Temp 0.41 & - \\
\hline Syringa vulgaris & Temp $0.71^{\star * *}$ & - & - \\
\hline
\end{tabular}

leaves because the substrates and enzymes of this reaction are localized in different organelles. During the destruction of tissues, specific glycosidases eliminate sugar, and cyanohydrin as an intermediate product decays to yield ketone or aldehyde and HCN (Roshchina V.V., Roshchina V.D., 2012).

For the species having maximum PA values in the conditions of drought (July), we have stated a strong relation to the air temperature $(\mathrm{B}>0.75)$ - Populus simonii Carriér, Salix alba L., Tilia cordata Mill., Morus alba L., Armeniaca vulgaris L., Robinia pseudoacacia L., Aesculus hippocastanum L., Acer platanoides L., A. pseudoplatanus L. (Table 3). For example, PA of Tilia cordata increases with a decrease in humidity $\left(\mathrm{R}^{2}=0.87\right)$. In this group prevail drought-resistant species, which are 


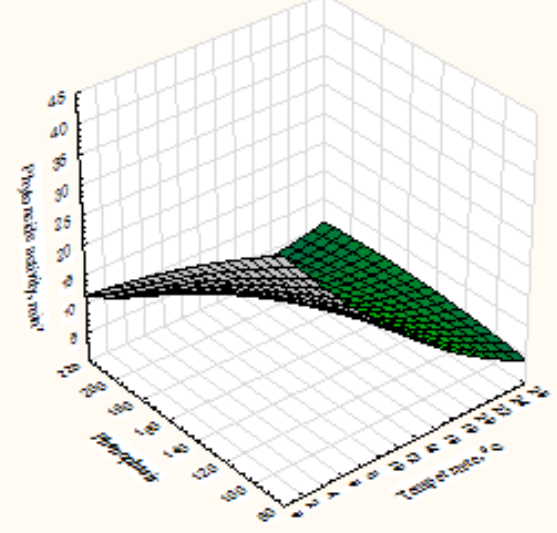

b 3D Surface Plot

Spreadsheet Padus avium $36 \mathrm{v}^{* 50 \mathrm{C}}$

$P A=15,8275+0,1319^{*} x-0,088^{*} y-0,0001^{*} x^{*} x-0,001^{*} x^{*} y+0,0002^{*} y^{*} y$

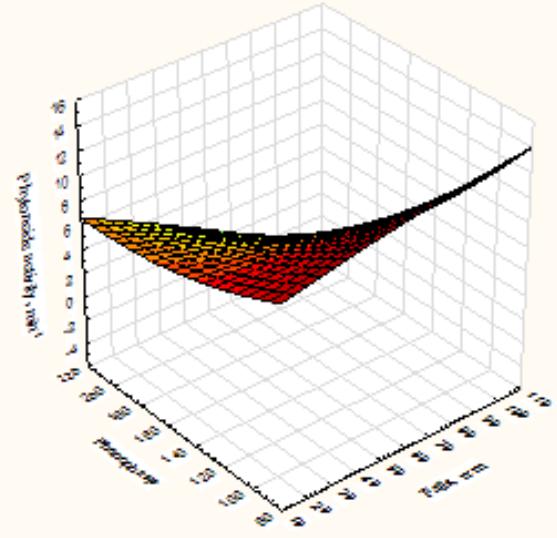

Fig. 2. Seasonal changes in the phytoncide activity of Padus avium Mill. depending on the phenophase and air temperature (a), and the phenophase and precipitation (b). 
xero-mesophytes and xerophytes. They activate the processes of osmotic regulation, stabilization of cell membranes, detoxification of toxic metabolic products, change hormonal regulation of metabolism and continue the synthesis of secondary metabolites in drought. Aesculus hippocastanum, Acer platanoides and A. pseudoplatanus are mesophytes and they release a certain amount of BVOC to cool the leaf sheet, and so the effect of high temperature is reduced.

Different mechanisms of increase in PA in August, 2011 are assumed. Drought were determined in August 2011, and 49\% of normal precipitation fell in the month, as shown in the Figure 1b. The introduced species and mesophytes indigenous species (Sorbus aucuparia L., Acer negundo L., Viburnum opulus L.), which are poorly adapted to the arid conditions of the Southeast of Ukraine BVOC are used as one of the mechanisms of decreasing the leaf temperature. Highly drought-resistant species Ulmus pumila L., Armeniaca vulgaris L., Pyrus communis L., Aillanthus altissima (Mill.) Swingle, Syringa vulgaris L. have shown these mechanisms in another way, due to their adaptive reactions to dry conditions. The strong and moderate direct relation to the air temperature has been established for these species.

From the standpoint of plant physiology, mechanisms of action of high temperature on the emission of volatile compounds are not completely revealed. They are of great interest, however, since the regulation of BVOC emission by plants at drought is closely related to global warming. Severe drought reduces the release of monoterpenes, but at the beginning of moisture deficit a flow of monoterpenes grows. In severe drought stomata close, transpiration stops, so BVOC are not emitted any more (Harley et al., 2014). The papers show that at extremely high temperature, one can observe the increased release of monoterpenes, located in cell compartments until the destruction of membranes. On the contrary, monoterpenes, sesquiterpenes and phenols formed under stress are reduced (Kleist et al., 2012; Pag et al., 2013).

Highly drought-resistant species showed the direct strong and moderate regressive relation to the air temperature. In conditions of normal humidity and high temperature, these species have maximal PA, but then it decreases in drought due to stopped transpiration and closed stomata at very low humidity. Most of the species are either indigenous or introduced from North America and China, and are adapted to local hydrothermal conditions. According to Polyakov (2009), the high drought-resistance is typical for the majority of the species from Circumboreal, Atlantic North American and Iran-Turan floristic regions, growing in urban conditions of Donbas. The species from East Asian and Mediterranean floristic regions are significantly less droughtresistant.

Due to the moisture deficit in summer in the south-east of Ukraine, most of the studied species are high and medium drought-resistant. They are widely used in planting in the cities of this territory and adapted to local microclimatic conditions (Polyakov, 2009). The transpiration of non-resistant species is disturbed because of turgor loss; also, there are violations in the synthesis of secondary metabolites, therefore, the phytoncide activity of these species decreases. So, the maximum phytoncide activity of Aesculus hippocastanum was noted on July 2011, while the drought was observed in August. However, the specimens of $A$. hippocastanum were affected by a leaf-mining moth. Kleist et al. (2012), Grote et al. (2013) and their colleagues note that the amount of BVOC at high temperature decreased under the biotic stress in mesophytes woody species.

It is necessary to single out the species, for which no regressive relationship between the air humidity and antiprotozoal activity was defined $(\mathrm{B}<0.45)$ - Junglans regia L., 
T a b l e 4. Antiprotozoal activity $\left(\mathrm{min}^{-1}\right)$ of deciduous woody plants over the vegetative period of 2010 , all the data is significant at $\mathrm{p} \leq 0.05$, bold type - antiprotozoal activity peak.

\begin{tabular}{|c|l|c|c|c|c|c|}
\hline \multirow{2}{*}{ No. } & Species & \multicolumn{4}{|c|}{ Months } \\
\cline { 2 - 6 } & & May & June & July & August & September \\
\hline 1 & Populus bolleana & $6.5 \pm 0.26$ & $5.5 \pm 0.10$ & $\mathbf{7 . 4} \pm \mathbf{0 . 2 5}$ & $7.3 \pm 0.25$ & $3.9 \pm 0.13$ \\
\hline 2 & P. canadensis & $5.6 \pm 0.18$ & $6.3 \pm 0.13$ & $7.5 \pm 0.19$ & $\mathbf{1 0 . 6} \pm \mathbf{0 . 1 8}$ & $5.2 \pm 0.15$ \\
\hline 3 & Tilia cordata & $14.3 \pm 1.51$ & $17.0 \pm 0.97$ & $18.7 \pm 1.22$ & $\mathbf{1 9 . 5} \pm \mathbf{0 . 7 1}$ & $7.0 \pm 0.42$ \\
\hline 4 & Robinia pseudoacacia & $6.0 \pm 0.18$ & $7.7 \pm 0.46$ & $8.4 \pm 0.40$ & $\mathbf{8 . 5} \pm \mathbf{0 . 4 3}$ & $4.0 \pm 0.08$ \\
\hline 5 & Aesculus hippocastanum & $7.7 \pm 0.39$ & $8.8 \pm 0.32$ & $11.0 \pm 0.39$ & $\mathbf{1 3 . 1} \pm \mathbf{1 . 0}$ & $7.6 \pm 0.42$ \\
\hline 6 & Acer platanoides & $10.7 \pm 0.62$ & $\mathbf{1 1 . 5} \pm \mathbf{0 . 3 1}$ & $10.3 \pm 0.30$ & $9.0 \pm 0.27$ & $7.2 \pm 0.30$ \\
\hline 7 & A.pseudoplatanus & $\mathbf{8 . 0} \pm \mathbf{0 . 3 2}$ & $7.9 \pm 0.14$ & $7.0 \pm 0.14$ & $7.4 \pm 0.10$ & $6.1 \pm 0.15$ \\
\hline 8 & Fraxinus excelsior & $\mathbf{6 . 5} \pm \mathbf{0 . 1 7}$ & $5.9 \pm 0.06$ & $5.8 \pm 0.09$ & $5.1 \pm 0.12$ & $4.4 \pm 0.04$ \\
\hline
\end{tabular}

T a b l e 5. Stepwise regression analysis for phytoncide activity of woody plants in the vegetative period of 2010. Negatively correlated variables are made in bold. Statistical significance, $\mathrm{p}$-value: $<0.05={ }^{*} ;<0.001={ }^{\star *} ;<0.0001^{\star * \star}$.

\begin{tabular}{|l|l|l|l|}
\hline Species & Step 1 & Step 2 & Step 3 \\
\hline Populus bolleana & Temp $1.95^{* * *}$ & Hum $0.79^{* * *}$ & Falls $0.74^{* *}$ \\
\hline P. $\times$ canadensis & Temp $1.18^{* * *}$ & Falls $0.69^{* *}$ & Hum 0.46 \\
\hline Tilia cordata & Temp $1.44^{* * *}$ & Hum $1.16^{* *}$ & - \\
\hline Robinia pseudoacacia & Temp $1.30^{* * *}$ & Hum $1.24^{* *}$ & Falls 0.61 \\
\hline Aesculus hippocastanum 2010 & Temp $1.10^{* *}$ & - & - \\
\hline Acer platanoides & Hum $1.87^{* *}$ & Temp $0.78^{*}$ & Falls $-1.01^{*}$ \\
\hline A. pseudoplatanus & Temp 0.89** & - & - \\
\hline Fraxinus excelsior & Hum $1.51^{* *}$ & Temp $1.17^{* *}$ & - \\
\hline
\end{tabular}

Notes: Temp -Temperature, Hum - Humidity, Falls - Falls.

Populus bolleana Lauche, $P . \times$ canadensis Moench, P. simonii Carriére, Armeniaca vulgaris L., Malus niedzwetzkyanna Dieck, Acer pseudoplatanus, Symphoricarpos albus L., Forsythia ovate Nakai, Ligustrum vulgare L. and Siringa vulgaris L. (Table 3). The antiprotozoal activity of these species was evenly increasing during the dry period, decreasing in autumn.

The basic data, typically for hydrothermal conditions of the Southeast of Ukraine, is expedient to be compared to that, when a severe drought was observed (Fig. 1a). The precipitation during this vegetative growth of species in August was 5\% of the normal amount. Multiple stepwise regression analysis for Populus bolleana, $P . \times$ canadensis, Tilia cordata, Robinia pseudoacacia, Aesculus hippocastanum, Acer pseudoplatanus, Fraxinus excelsior showed that the temperature was a major factor, as in the previous year, as shown in the Table 4 and 5. The second important factor is air humidity.

Under the influence of a deep long-lived drought for representatives of the genus Populus (Populus bolleana, $P . \times$ canadensis), it is stated that meteorological factors have a significant influence on the antiprotozoal activity of leaves. In the case of $P$. bolleana, the most influence is 
produced by a factor of humidity. For $P . \times$ canadensis, precipitation is more important because it has more moisture like woody plant. This pattern is observed under more favourable conditions (2011).

In 2010, highly drought-resistant species Tilia cordata, Robinia pseudoacacia showed a high PA under the conditions of most severe drought and moisture deficit, while mesophytic species revealed a drop in antiprotozoal activity and a strong relation to the air humidity.

The analysis of changes in the antiprotozoal activity of leaves of the studied species revealed the important role of air humidity for PA dynamics. Regressive relationships between the antiprotozoal activity of the studied species and the relative air humidity give a better explanation for the phytoncide activity dynamics under hydrothermal stress. The high and moderate negative coefficients of correlation between PA and air humidity in 2011 were observed for the species having the maximum antiprotozoal action of volatile compounds in the hottest month, that is consistent with the available evidence. So, V.V. Slepyih and other authors note the peak of phytoncide activity in the hottest summer month with low air humidity (Slepyih, 2004; Steinbrecher et al., 2009; Oderbolz et al., 2013).

Thus, air temperature is proved to be a major factor defining the seasonal dynamics of phytoncide activity. Majority of investigating species have maximum phytoncide activity in the phase of second growth of shoots, in the summer. Such a tendency is due to the peculiarity of biological processes of these plants. The antiprotozoal activity of the woody plant species that are poorly adapted to the heat increases under hydrothermal stress, as an adaptation to low humidity and high temperatures of air, but the common activity of plants in areas with drought period at these species are low and in the urbanized conditions, it affects a state of the assimilatory device. The maximum phytoncide activity of high and medium resistant woody plant species occurs in the month when temperature is high, but humidity is normal, as highly phytoncide plants. These species (Populus simonii, Salix alba, Morus alba, Robinia pseudoacacia, Ulmus pumila, Aillanthus altissima) activate the preadaptive mechanisms to adverse growth conditions. They are the most perspective woody plants to use in the urbanized territories with an arid climate for improvement of ecological state and normalisation of the atmosphere.

\section{References}

Davison, B., Taipale, R., Langford, B., Misztal, P., Fares, S., Matteucci, G., Loreto, F., Cape, J.N., Rinne, J. \& Hewitt C.N. (2009). Concentrations and fluxes of biogenic volatile organic compounds above a Mediterranean macchia ecosystem in western Italy. Biogeosciences, 6, 1655-1670. DOI: 10.5194/bg-6-1655-2009.

Dewulf, J., Joó, É., Van Langenhove, H., Pokorska, O., Van Langenhove, H., Steppe, K., Lemeur, R., Šimpraga, M., Verbeeck, H., Bloemen, J., Demarcke, M., Amelynck, C., Schoon, N., Müller, J.-F., Laffineur, Q., Aubinet, M. \& Heinesch B. (2012). Impact of phenology and environmental conditions on BVOC emissions from forest ecosystems IMPECVOC. Final Report. Brussels: Belgian Science Policy (Research Programme Science for a Sustainable Development). http://www.impecvoc.ugent.be

Duhl, T.R., Helmig, D. \& Guenther A. (2008). Sesquiterpene emissions from vegetation: a review. Biogeosciences, 5, 761-777. DOI: 10.5194/bg-5-761-2008.

Fowler, D. (2002) Pollutant deposition and uptake be vegetation In J.N.D. Dell \& M. Treshow (Eds.), Air pollution and plant life (pp. 43-69). West Sussex: John Wiley \& Sons Ltd.

Fuentes, J.D., Lerdau, M., Atkinson, R., Baldocchi, D., Bottenheim, J.W., Ciccioli, P., Lamb, B., Geron, C., Gu, L., Guenther, A., Sharkey, T.D. \& Stockwell W. (2000). Biogenic hydrocarbons in the atmospheric boundary layer: A review. Bulletin of the American Meteorological Society 81 (7), 1537-1575. https://www.jstor.org/stable/26215178

Grodzinskiy, A.M. (1973). Fundamentals of chemical interaction of plants (in Russian). Kiev: Nauk Dumka. 
Grote, R., Monson, R. \& Niinements Ü. (2013). Leaf-level models of constitutive and stress-driven volatile organic compound emissions. In Ü. Niinements \& R. Monson (Eds.), Biology, controls and models of tree volatile organic compound emissions (pp. 315-355). Dordrecht: Springer Science and Business Media.

Guenther, A., Karl, T., Harley, P., Wiedinmyer, C., Palmer, P.I. \& Geron C. (2006). Estimates of global terrestrial isoprene emissions using MEGAN (Model of Emissions of Gases and Aerosols from Nature). Atmospheric Chemistry and Physics, 6, 3181-3210. DOI: 10.5194/acp-6-3181-2006.

Guenther, A.B., Jiang, X., Heald, C.L., Sakulyanontvittaya, T., Duhl, T., Emmons, L.K. \& Wang X. (2012). The model of emissions of gases and aerosols from nature version 2.1 (MEGAN2.1): an extended and updated framework for modeling biogenic emissions. Geoscientific Model Development, 5, 1471-1492. DOI: 10.5194/gmd-5-1471-2012.

Harley, P., Eller, A., Guenther, A. \& Monson R.K. (2014). Observations and models of emissions of volatile terpenoid compounds from needles of ponderosa pine trees growing in situ: control by light, temperature and stomatal conductance. Oecologia, 176, 35-55. DOI: 10.1007/s00442-014-3008-5.

Harley, P.C. (2013) The roles of stomatal conductance and compound volatility in controlling the emission of volatile organic compounds from leaves biology. In Ü. Niinements \& R. Monson (Eds.), Controls and models of tree volatile organic compound emissions (pp. 181-208). Dordrecht: Springer Science and Business Media.

Hopke, P.K. (2009). Theory and application of atmospheric source apportionment. In A.H. Legge (Ed.), Air quality and ecological impacts: relating sources to effects (pp. 99-121). Elsevier.

Kesselmeier, J. \& Staudt M. (1999). Biogenic volatile organic compounds (VOC): an overview on emission, physiology and ecology. Journal of Atmospheric Chemistry, 33, 23-88. DOI: 10.1023/A:1006127516791.

Kleist, E., Mentel, T.F., Andres, S., Bohnel, A., Folkers, A., Kiendler-Scharr, A., Rudich, Y., Springer, M., Tillmann, R. \& Wildt J. (2012). Irreversible impacts of heat on the emissions of monoterpenes, sesquiterpenes, phenolic BVOC and green leaf volatiles from several tree species. Biogeosciences, 9, 5111-5123. DOI: 10.5194/bg-9-5111-2012.

Korshikov, I.I. (2004). Stability of plants to technogenic pollutants of the environment (in Russian). Industrial Botany, 4, 46-58.

Kulagin, Yu.Z. (1985). Industrial dendroecology and forecasting (in Russian). Moscow: Nauka.

Lipinskogo, V.M., Dyachuka, V.A., Babichenko V.M. (Eds.) (2003). Climate of Ukraine (in Ukrainian). Vid-vo Raevskogo.

Methodology of phenological observation in the USSR Botanical Gardens (1979). Byul. Gl. Botan. Sada, 113, 3-8.

Oderbolz, D.C., Aksoyoglu, S., Keller, J., Barmpadimos, I., Steinbrecher, R., Skjøth, C. A., Plaß-Dülmer, C. \& Prévôt A.S.H. (2013). A comprehensive emission inventory of biogenic volatile organic compounds in Europe: improved seasonality and land-cover. Atmospheric Chemistry and Physics, 13, 1689-1712. DOI: 10.5194/acp-13-1689-2013.

Pag, A., Bodescu, A., Kännaste, A., Tomescu, D., Niinemets, Ü. \& Copolovici L. (2013). Volatile organic compounds emission from Betula verrucosa under drought stress. Scientific Bulletin of ESCORENA, 8, 45-53.

Pennuelas, J. \& Llusia J. (2001). The complexity of factors driving volatile organic compounds emissions by plants. Biol. Plant. 44(4), 481-487. DOI: 10.1023/A:1013797129428.

Polyakov, A.K. (2009). Introduction of woody plants in the conditions of technogenic environment (in Russian). Donetsk: Noulidzh.

Roschina, V.V. \& Roschina V.D. (2012). Excretory function of higher plants (in Russian). Elektronnoe izdatelstvo "Analiticheskaya mikroskopiya". Elektronnyiy resurs : http://cam.psn.ru

Slepyih, V.V. (2004) Natural and antropogenic factors and phytoncide activity of woody plants (in Russian). Lesn. hoz-vo, $6,17-19$.

State of the Natural Environment (2010). In S.Tretyakov \& G.Averin (Eds.), The land of our concern. Based on material from Reports on the state of the natural environment in Donetsk Oblast (pp. 45-48).

Steinbrecher, R., Smiatek, G., Koëble, R., Seufert, G., Theloke, J., Hauff, K., Ciccioli, P., Vautard, R. \& Curci G. (2009). Intraand inter-annual variability of VOC emissions from natural and seminatural vegetation in Europe and neighbouring countries. Atmos. Environ., 43, 1380-1391 DOI: 10.1016/j.atmosenv.2008.09.072.

Tokin, B.P. (1980). Medicinal poisons of plants (in Russian). Leningrad.

Zaitseva, I.O. (2003). Research of phenorytmics of woody plants (in Ukrainian). Dnipropetrovsk: Dnipropetrovsk National University. 